\title{
Institutional Pressures and Corporate Green Innovation; Empirical Evidence from Chinese Manufacturing Enterprises
}

\author{
Shengnan Ning ${ }^{1,2,3}$, Xiaowen Jie ${ }^{1,2}$, Xiaoping $\mathrm{Li}^{1 *}$ \\ ${ }^{1}$ School of Business, Sichuan University, Chengdu 610065, China \\ ${ }^{2}$ Strategy and Development Research Center of Sichuan University, Chengdu 610065, China \\ ${ }^{3}$ Department of Business Technology and Operations, Vrije Universiteit Brussel, Brussels, Belgium
}

Received: 2 April 2021

Accepted: 5 July 2021

\begin{abstract}
This paper addresses the longstanding debate about whether institutional pressures enhance or suppress corporate green innovation. Grounded in institutional and sustainable development theories, this paper empirically tested the impact of institutional pressures on corporate green innovation by applying a fixed effect negative binomial regression model to a research sample of listed Chinese manufacturing companies from 2012 to 2017. It was found that regulatory, normative, and mimetic pressures had significant positive effects on corporate green innovation, and that under external environmental protection pressure, companies became involved in green innovation activities to maintain their legitimacy and competitive advantage. The moderating effect of the pollution intensity and marketization variables, both of which affect the green innovation resource efficiency, were only found to play a role under regulatory and mimetic pressures. These research findings provide strategic guidance for green innovation development in manufacturing enterprises and provide the basis for future government environmental protection policies.
\end{abstract}

Keywords: institutional theory, green innovation, regulatory pressure, normative pressure, mimetic pressure

\section{Introduction}

Environmental incidents such as corporate pollution and smog have caused significant public concern in the past decade, which has forced governments to focus more on sustainable, clean green development [1]. In China, specific energy consumption is much higher

*e-mail: lixiaoping@scu.edu.cn than that of the United States, the European Union, Japan and other developed countries. The total amount of disposable energy consumption accounts for about $20 \%$ of the world's total energy consumption, and the total energy consumption of industries accounts for $63 \%$ of the country's total energy consumption, and the total amount of major pollutants basically exceeds the environmental carrying capacity [2]. At the General Debate of the $75^{\text {th }}$ Session of the United Nations General Assembly, President Xi announced China's initiative 
to scale up its nationally determined contributions and strive to peak carbon dioxide emissions by 2030 and achieve carbon neutrality by 2060 . To meet this pledge, the Chinese government promulgated and implemented a range of energy conservation and emissions reductions policies, which resulted in many companies being penalized for their environmentally unfriendly behaviors, which in turn disappointed their respective consumers causing them to lose market share [3]. Therefore, to cope with the increasing environmental pressures from government, society and consumer, enterprises need to develop innovative green strategies to improve their products, manufacturing processes, technologies, and systems [4].

Because of its high risk, high investment and long return cycle characteristics, green innovation, which is considered an active response to environmental pressures, is different from passive response behaviors that only seek to meet minimum policy standards [5]. Compared with other green practices, such as green logistics, green purchasing and green marketing, green innovation requires greater financial support and usually only results in long term returns [6]. As green innovation involves the development of new products and processes to reduce or eliminate the use and generation of harmful substances, it has certain spillover effects. Meanwhile green innovation reduces external environmental production costs to produce external effects. That is, green innovation has dual externalities [7]. It has been argued that green innovation has become a key area of competitive advantage as it can add value to the major stakeholders and maintain and attract customers [8, 9]. In this study, green innovation is defined as green products or processes, such as energy saving, pollution prevention, waste recovery, green product design or enterprise environmental management.

Institutional pressure has been recognized as one of the key driving forces for green innovation [10-12]. As enterprises are in a social network, their behavior and decision-making are often affected by the stakeholders. Therefore, it is more appropriate to explain the enterprises behavior from the perspective of social atmosphere impact, not only from the economic and rational perspective of the enterprise. More and more researchers believe that enterprises can improve their ability to survive and develop in the fierce competition environment through meeting the needs of their external stakeholders. Institutional pressures are mainly divided into three types: regulatory pressure (from the government), normative pressure (from nongovernment organizations) and mimetic pressure (from competitors) [13-14]. However, compared with traditional innovation research, we found that most frontier green innovation research had been conducted in high-income developed countries, with very little focused on developing countries [15]. To date, there have been two different research foci, the first of which takes a traditional economic view that institutional pressures reduce enterprise motivation to invest in green innovation [16], and the second of which believes that environmental regulations can motivate enterprise innovation, which is known as the Porter hypothesis [17].

Institutional theory defines green innovation as the environmental innovation organizational practices that legitimize responses to institutional pressures. Under the background of the contradiction between China's manufacturing resource constraints and environmental pollution, the transformation of enterprises green innovation is more significant. As many studies have found that institutional pressure can have a driving effect on green enterprise practice [18], based on innovation focused literature and institutional theory, this study surmised that the higher the regulatory, normative, and mimetic pressures, the higher the enterprise motivation to participate in green innovation, which was tested using panel data from listed Chinese manufacturing firms, from which it was found that the empirical results were consistent with the study hypotheses.

This study makes several contributions to current theoretical research. First, it provides support for the weak Porter hypothesis, deepens the empirical research on corporate green innovation, examines the situation in a typical developing country, and clarifies the strong relationships between institutional pressures and green innovation. Second, although the pollution intensity and marketization degree in the area where an enterprise is located were found to have an effect on the resource efficiency required for corporate innovation, the moderating effect of these two factors on enterprise innovation has rarely been investigated; therefore, this study enriches knowledge on the relationship between institutional pressures and corporate green innovation.

\section{Data and Methodology}

\section{Theoretical Framework and Hypotheses}

\section{Institutional Pressures and Green Innovation}

Enterprises are inevitably bounded by the institutional environment. The institutional environment forces enterprises to comply with external rules, norms and values. Institutional theory has been used for several years to explain enterprise behavior [19-21]. Institutional theory holds that enterprises are committed to the pursuit of legitimacy, namely, the acceptance and approval of their institutional environment, which has a significant impact and pressure on their organizational behavior [22].

Three main institutional pressures have been identified: regulatory pressure, normative pressure, and mimetic pressure [6]. Although these three institutional pressures have often been observed to operate at the same time, they have different green innovation moderating roles. It has been found that regulatory (e.g., 
governmental agencies) and normative (e.g., professional non-government organizations) and mimetic agents are the main institutional actors in environmentally sensitive industries [23].

\section{Regulatory Pressures and Green Innovation}

Regulatory pressure is related to the formal and informal pressures on enterprises from government and institutional regulations and policies [24]. To date, the Chinese government has promulgated several laws related to its sustainable development aims, such as the Clean Production Promotion Law (2002), the Circular Economy Promotion Law (2018), the Environmental Information Disclosure Guide for Listed Companies (2010), and the new Environmental Protection Law of the People's Republic of China (2014), all of which require enterprises to fulfill their environmental responsibilities. Regulatory pressure is inviolable, that is, if companies do not comply, they pay a high price, such as economic fines, reduction in their social image and relationships, and a possible negative effect on sales and long-term business prospects [25,26].

Under increasing regulatory pressure, enterprises would be more motivated to engage in environmental innovation to avoid both political and economic costs. Xie (2017) found that government environmental standards and the fear of mandatory regulations such as warnings, supervision, or punishments were the main motivations for enterprise adoption of environmental behaviors [27]. Rubashkina (2015) found that incentive regulations such as market-based preferential policies were instrumental in motivating green SME innovation [28], and Li (2017) concluded that environmental technology information, cooperative platforms, special support funds, and other means provided green innovation support for enterprises that needed multiple cooperation and diversified upstream and downstream industry knowledge [29]; therefore, the following hypothesis is proposed.

Hypothesis 1: As environmental regulatory pressure increases, green innovations accordingly increase.

\section{Normative Pressure and Green Innovation}

Normative pressure generally comes from professional organizations and social groups, such as industry associations and non-government organizations (NGO). In China, the influence of industry associations on enterprises is extremely weak [30]. It has been found that although NGOs are external stakeholders and not necessarily part of formal enterprise channels, they have the power to influence organizational processes [31]. However, different from regulatory pressure, normative pressure exerts an influence on corporate behavior through positive guidance. Different from regulatory pressure, which is compulsory, normative pressure is comprised of soft constraints on enterprises.
Environmental NGOs are nonprofit organizations with rich environmental protection expertise, and a commitment to environmental protection and environmental solutions. Enterprises that implement environmental governance are often strongly supported through environmental NGO publicity and marketing, which provides various tangible and intangible resources. Compared with regulatory pressure, as normative pressure is more likely to result in reputational and competitive advantage, enterprises may seek to willingly implement green innovation strategies. Because environmental NGOs are also able to provide the knowledge needed to generate unique and possibly disruptive ideas [32], they can inspire novel solutions and new value-creating enterprises strategies [33]; therefore, the following hypothesis is proposed.

Hypothesis 2: As the environmental normative pressure arising from NGOs increases, green innovation accordingly increases.

\section{Mimetic Pressure and Green Inovation}

Mimetic pressure comes from organizational behavioral perceptions of competitors in the social network. The influence of mimetic pressure on environmental responsibility system theory has identified imitation behavior as being a reflection of uncertainty. Therefore, to cope with the market competition and reduce uncertainty or reduce decisionmaking errors, enterprises often perceive the decisionmaking behavior of leading industry enterprises as a benchmark, and then seek to emulate their behaviors [34], with this desire to imitate being the root of the mimetic pressure to generate green innovations. Zhu (2016) concluded that enterprises were willing to take environmental certification action to deal with the competitive pressures from other industry enterprises that had already been certified [35]. However, while mimetic pressure is not necessarily conducive to improvements in the internal performances of the organization, it is seen as providing legitimate recognition and reputation to the organization. Lin et al. (2020) pointed out that effective green innovation has become an important source of differentiation for enterprises to establish competitive advantage [36]. Zhu and Geng's (2013) research on Chinese manufacturing enterprise supply chains revealed that mimetic pressure was also an important driving force for enterprises to achieve energy conservation and emissions reduction goals [37]. Therefore, mimetic pressure can impel enterprises to voluntarily emulate competitors when making environmental protection and green innovation decisions to catch up with the "lead" enterprise in the same industry; therefore, the following hypothesis is proposed.

Hypothesis 3: As environmental mimetic pressure increases, green innovation accordingly increases. 


\section{Moderating Role of Pollution Intensity}

Regional sustainable development theory states that the basic development condition is ecological environmental protection. As China's economy enters a new normal, enterprises need to transition from an "environmentally friendly strategy" to a "forwardlooking environmental strategy" that proactively and voluntarily deals with environmental problems and promotes source control environmental measures. While most existing research has been focused on analyzing the moderating role of industrial pollution intensity, regional pollution intensity has rarely been examined. However, this study surmised that the higher the regional pollution level, the stronger the environmental protection motivations of the local enterprises [38]. Enterprise environmental protection and green innovation motivation have also been confirmed in some studies; for example, Cho (2018) found that there was a significant positive correlation between the number of green patent applications and the price of corporate emissions reductions [39], and Ding (2015) found that pollution reduction expenditure had a positive impact on the number of environmental patents in China [40]. Therefore, enterprise environmental strategic behaviors are often linked to the enterprise understanding of the objective external institutional pressures, that is, an enterprise's response to green innovation is related to their understanding of the institutional pressures, which means that regional pollution intensity can act as a moderating factor for the expansion or shrinking influence of the external institutional environment; therefore, the following hypotheses are proposed.

Hypothesis 4a: Pollution intensity moderates the relationship between regulatory pressure and green innovation.

Hypothesis 4b: Pollution intensity moderates the relationship between normative pressure and green innovation.

Hypothesis 4c: Pollution intensity moderates the relationship between mimetic pressure and green innovation.

\section{Moderating Role of Marketization}

The resource-based view is that a firm's behavior is determined by its resource base, with its commensurate response to institutional pressures depending on resource adequacy [41]. As enterprises in regions that have high marketization are able to obtain the innovation resources they need from the market, the possibility of "market failure" is low because: (1) to promote R\&D capital accumulation, social funds can be invested in enterprise $R \& D$ activities through financial institutions [42]; (2) the competition mechanism is the confidence commitment the market transmits to the enterprise, which encourages the enterprise to pay greater attention to R\&D quality and efficiency [43]; and (3) in high marketization regions, improvements in the legal system and the development of intermediary market organizations both strengthens the protection of the enterprise intellectual property rights, which stimulates R\&D innovations, and shortens the enterprise innovation cycle due to unimpeded R\&D overflow channels [44]. Therefore, compared to regions with low marketization, when enterprises are able to obtain the innovation resources needed from the market, the institutional pressure effect is enhanced. Because the market has a stronger resource allocation function in regions with high marketization, the perceived institutional pressure on enterprises is more likely to promote corporate green innovation; therefore, the following hypotheses are proposed.

Hypothesis 5a: The degree of marketization moderates the relationship between regulatory pressure and green innovation.

Hypothesis 5b: The degree of marketization moderates the relationship between normative pressure and green innovation.

Hypothesis 5c: The degree of marketization moderates the relationship between mimetic pressure and green innovation.

\section{Research Methodology}

\section{Dependent Variable: Corporate Green Innovation}

Previous research has generally measured green innovation using various indicators, such as the rate of adoption of green management systems [45], the extent of green $R \& D$ [46], the ratio of $R \& D$ input to energy consumption [47], the number of issued patents [5], and whether or not the enterprise had an ISO14001 or similar eco-labeling product certification [48]. Therefore, this study chose to measure corporate green innovation from the green patent authorization (green invention patents and green utility model patents) data in each of the listed companies.

In the United Nations Framework Convention on climate change, the "IPC green inventory" of world intellectual property organization (WIPO) classified green patents into seven categories; transportation, waste management, energy conservation and alternative energy production, administrative regulation or design aspects, agriculture or forestry, and nuclear power generation; and covered about 200 topics that were directly related to environmentally friendly technologies. Therefore, as the core measurement index for corporate green innovation, in accordance with the above classification standards, this paper used a comparison of the National Intellectual Property Administration to identify and calculate the number of green enterprise patents. 


\section{Explanatory Variables and Moderators}

(1) Regulatory pressure

Various measurement methods have been used to measure regulatory pressures. For example, Berrone et al. (2013) used the ratio of the total number of inspections and the total number of regulated entities (divided by one thousand) to obtain a measure of the state level of regulatory pressure [5], and Luo and Zhang used the environmental administrative regulations issued by the local governments in each province [49]. This study measured the regulatory pressure based on the number of companies that were being especially supervised by the ecological environmental bureaus in the respective administrative regions in which the enterprises were located because of soil environment, heavy metal emission, wastewater pollution, and exhaust gas pollution problems. Given the non-normality of the distribution for this variable, a logarithmic transformation was applied before it was included in the model.

(2) Normative pressure

The normative pressure was proxied using information regarding the number of Environmental Non-Government Organizations (ENGOs) per year as stated in the China development brief, which is the Chinese national nonprofit sector data repository, with the total ENGOs being divided by the total number of regulated entities per year at the provincial level. Again, because of the non-normality of the distribution for this variable, a logarithmic transformation was applied before it was included in the model.

(3) Mimetic pressure

As in $\mathrm{Li}$ (2016), the Herfindahl-Hirschman Index (HHI) was employed to measure the degree of product market competition [50], with the main business income in each company being used to calculate its respective market share in the industry, where $\mathrm{Xi}$ was the main business income in a single company, $\mathrm{X}$ was the total main business income of the industry to which the company belongs, and $\mathrm{Xi} / \mathrm{X}$ was the industry market share occupied by the company, with the HHI being the sum of the square of the ratio of the main business income of each company in the industry to the total main business income of the industry.

$$
\mathrm{HHI}=\operatorname{sum}\left[\left(\mathrm{X}_{\mathrm{i}} / \mathrm{X}\right)^{\wedge} 2\right]
$$

\section{(4) Pollution intensity}

As in Cole \& Elliott (2003), this study adopted a linear standardization method to deal with the pollution intensity index [51], construct an index system that comprehensively reflected the pollution density in the different regions, and measure the pollution intensity in each region, with the emissions value per unit output of pollutants in each province being calculated from the waste water, gas, and solid and industrial output pollution emissions in each province. The unit pollution emissions in each region were then linearly standardized and a weighted average calculated to finally determine the pollution intensity, the specific steps for which are detailed in the following.

First, the pollutant emissions values per unit output values in each province were linearly standardized, where UEij was the emissions value per unit output value of $\mathrm{j}$ pollutant in province $\mathrm{i}, \max (\mathrm{UEj})$ and $\min$ (UEj) respectively represented the maximum and minimum emissions values per unit output value of the pollutants in different provinces, and UESij was the standardized emissions value per unit output value of the pollutant as shown in Equation (2).

$$
\mathrm{UES}_{\mathrm{ij}}=\left[\mathrm{UE}_{\mathrm{ij}}-\min \left(\mathrm{UE}_{\mathrm{j}}\right)\right] /\left[\max \left(\mathrm{UE}_{\mathrm{j}}\right)-\min \left(\mathrm{UE}_{\mathrm{j}}\right)\right]
$$

Second, the adjustment coefficient for each index $\left(\mathrm{W}_{\mathrm{j}}\right)$ was calculated. As the provincial pollution situations vary widely because of developmental, geographical, and climatic differences, these pollution intensity differences were catered for by approximately adjusting the coefficient, where $\mathrm{n}$ means there were $\mathrm{n}$ provinces, the method for which was as shown in Formula (3).

$$
w_{i j}=\frac{U E_{i j}}{\sum_{i=1}^{n} U E_{i j}}
$$

Finally, the normalized value and the average weight of each individual index were used to calculate the pollution intensity, where $\mathrm{M}$ referred to $\mathrm{M}$ pollutants. The specific method for which is shown in Equation (4).

$$
P I S_{i}=\frac{\sum_{j=1}^{m} W_{i j} * U E S_{i j}}{m}
$$

\section{(5) Marketization}

The marketization was operationalized using the marketization index developed by Fan, Wang and Zhang (2003), which has been widely used to measure marketization in China as it is a comprehensive composite index that uses twenty-six indicators to evaluate the development of market-based mechanisms in each of China's regions in five key areas: the role of the market relative to the government; the development of the private sector; the development of commodity and factor markets; and the development of free market institutions: with the higher the score, the higher the regional marketization .

\section{Control Variables}

The variables were: (1) firm ownership, which was a dummy variable that was 1 if the firm was state-owned and 0 otherwise; (2) the listing age, which was the number of years since the firm was listed; (3) firm size, which was taken as the natural logarithm of its market value; and (4) financial leverage, which captured the firm's financial risk and was measured as the ratio of 
Table 1. Variables used in this research.

\begin{tabular}{|c|c|c|}
\hline Variables & Symbols & Measuring methods \\
\hline Green innovation & GI & $\begin{array}{l}\text { The number of green patents granted to enterprises, including green invention patents and green } \\
\text { utility model patents }\end{array}$ \\
\hline Regulatory pressure & $\mathrm{RP}$ & $\begin{array}{c}\text { The number of companies specially supervised by the ecological environment bureaus of the } \\
\text { administrative regions in which the enterprises were located }\end{array}$ \\
\hline Normative pressure & NP & $\begin{array}{c}\text { The total number of ENGOs/ the total number of regulated entities per year at the provincial } \\
\text { level }\end{array}$ \\
\hline Mimetic pressure & MP & Herfindahl-Hirschman Index \\
\hline Pollution intensity & PI & $\begin{array}{l}\text { The waste water, gas, and solid and industrial output pollution emissions in each province as } \\
\text { measured by the pollutant emissions values per unit output values }\end{array}$ \\
\hline Marketization degree & MI & Marketization Index \\
\hline Firm ownership & State & Dummy, 1 if the firm was state-owned firm \\
\hline List age & Age & The number of years since the firm was listed \\
\hline Firm size & Size & Logarithm of the market value \\
\hline Financial risk & FL & $\begin{array}{c}\text { Financial Leverage, (net income }+ \text { income tax expense }+ \text { financial expense) } /(\text { net income }+ \\
\text { income tax expense })\end{array}$ \\
\hline
\end{tabular}

net income, income tax expense, and financial expenses to net income and income tax expenses. Table 1 further summarizes the variables and their measurements.

\section{Sample and Data Collection}

Chinese A-share listed manufacturing companies between 2012 and 2017 were chosen as the sample, with the specific exclusions being financial industry companies, special treatment (ST) companies, companies that had had losses for over 2 years, environmental industries in which green innovation was not important and had not issued any green patents, companies that had been listed on the Chinese stock market for less than one year, and those whose listing had been terminated, and companies with incomplete financial data. Therefore, after this comprehensive screening, a final sample of 222 different companies was extracted.

The initial RP data were taken from the municipal ecology and environmental bureaus, the initial NP data were taken from the China development brief (http:// www. chinadevelopmentbrief.org.cn), the initial MP and control variable data were from the China Stock Market \& Accounting Research (CSMAR) and Wind Databases, the initial GI data were taken from WIPO and the national intellectual property administration, PRC, and the pollution intensity data were extracted from the official website of the Chinese National Bureau of Statistics and the official website of the Chinese provincial environmental protection bureaus.

\section{Empirical Model and Estimation Method}

The dependent variable was measured by the number of green patents, for which nonlinear estimators were used rather than linear regression. A preliminary exploratory analysis of the data using the Lagrange Multiplier test rejected the pure Poisson model in favor of a model in which the variance was proportional to the mean. Using mixed negative binomial regression and cluster robust standard error, it was found that there was excessive dispersion in the data, indicating that the negative binomial regression model was more efficient. Finally, based on the Hausmann test results, the Negative Binomial Regression Model with fixed effects was selected.

\section{Results and Discussion}

\section{Descriptive Statistics and Correlation Analysis}

Table 2 shows the descriptive statistics for the variables. The mean value for regulatory pressure was strong at 7.197 (range from 0 to 10), for normative pressure was weak at 0.659 (range from 0 to 3 ) and for mimetic pressure was also weak at 0.096 (range from 0 to 0.5 ). The mean pollution intensity was 0.35 , with a 0.327 standard deviation, which indicated that there was a certain degree of difference in the sample enterprise city pollution intensities. The minimum marketization index value was negative, which was related to a company in Tibet; however, to ensure comprehensive results, the corresponding data was retained. The means and standard deviations for state, age, size, and FL revealed the characteristics for the sample observations. All variables had good data difference performances, with any large differences being due to the basic enterprise properties, indicating that the sample enterprises differed significantly which enhanced the universality of the empirical conclusions. 
Table 2. Descriptive statistics.

\begin{tabular}{|c|c|c|c|c|}
\hline Variable & Mean & Std. Dev. & Min & Max \\
\hline GI & 2.245027 & 2.777511 & 0 & 8.72708 \\
\hline RP & 7.197423 & 0.9026575 & 4.948946 & 2.5 \\
\hline NP & 0.6594191 & 0.4257252 & 0 & 0.377983 \\
\hline MP & 0.0962937 & 0.0612653 & 0.008547 & 1.914538 \\
\hline PI & 0.3501732 & 0.3267767 & 0 & 10.29 \\
\hline MI & 7.763436 & 1.929379 & -1.14 & 1 \\
\hline State & 0.4963834 & 0.5002131 & 0 & 27 \\
\hline Age & 17.21519 & 6.287011 & 3 & 25.77061 \\
\hline Size & 22.94728 & 1.038051 & 20.82894 & 16.58372 \\
\hline FL & 2.087109 & 2.536716 & 0 & \\
\hline
\end{tabular}

Table 3. Correlations.

\begin{tabular}{|c|c|c|c|c|c|c|c|c|c|c|}
\hline & GI & RP & NP & MP & PI & MI & State & Age & Size & FL \\
\hline GI & 1 & & & & & & & & & \\
\hline RP & $0.185^{* * *}$ & 1 & & & & & & & & \\
\hline NP & $0.012^{*}$ & $-0.232^{* * *}$ & 1 & & & & & & & \\
\hline MP & $0.028^{* *}$ & $-0.129^{* * *}$ & -0.048 & 1 & & & & & & \\
\hline PI & $-0.091^{* * *}$ & $-0.577^{* * *}$ & 0.001 & $0.155^{* * *}$ & 1 & & & & & \\
\hline MI & $0.0544^{*}$ & 0.5569 & -0.1672 & -0.0321 & -0.5516 & 1 & & & & \\
\hline State & $-0.067^{* *}$ & -0.022 & -0.017 & $-0.101^{* * *}$ & -0.049 & 0.0142 & 1 & & & \\
\hline Age & $-0.103^{* * *}$ & $-0.178^{* * *}$ & $-0.055^{*}$ & $0.113^{* * *}$ & $0.141^{* * *}$ & -0.1871 & $0.395^{* * *}$ & 1 & & \\
\hline Size & $-0.082^{* * *}$ & $-0.162^{* * *}$ & 0.027 & -0.004 & -0.007 & 0.0013 & $0.247^{* * *}$ & $0.347^{* * *}$ & 1 \\
\hline FL & -0.008 & $0.065^{* *}$ & -0.047 & $-0.114^{* * *}$ & $-0.073^{* *}$ & 0.0134 & $0.105^{* * *}$ & $0.137^{* * *}$ & $0.126^{* * *}$ & 1 \\
\hline
\end{tabular}

Notes: ${ }^{* * *} \mathrm{p}<0.01,{ }^{* *} \mathrm{p}<0.05,{ }^{*} \mathrm{p}<0.1$.

Table 3 shows the correlation coefficient matrix between the variables. Generally, it is better to control the correlation coefficients between independent variables below 0.3 , with more than 0.7 indicating that there are serious collinearity problems and some variables needed to be eliminated or replaced. As shown, green innovation and the regulatory, normative and mimetic pressures were all significantly positive, which supported hypotheses 1, 2, and 3. Pollution intensity, marketization, firm ownership, age, and size were also found to be significantly correlated with green innovation.

\section{Hypothesis Testing}

\section{Main Effects}

As shown in Table 4, the main effect of the institutional pressures on green innovation was first examined. Models 1, 2, and 3, which respectively reflected the regulatory, normative, and mimetic pressures, were observed to have a positive and significant effect on a firm's green innovation; therefore, hypotheses 1, 2, and 3 were supported. In Model 4, as the coefficients for RP, NP, and MP were significant, and the coefficient symbol was consistent with that of the univariate regression, support was again provided for hypotheses 1,2 , and 3 .

\section{Moderating Effects}

In Model 5, GI and RP were significantly positively correlated at the $10 \%$ level, verifying hypothesis 1 , and GI was significantly positively correlated with the multiplication term RP*PI at the 5\% level, with its coefficient being the same as the RP regression coefficient, which indicated that pollution intensity was playing an enhanced moderating role on the effect 
of regulatory pressure on corporate green innovation. GI was also significantly positively correlated with the multiplication term RP*MI at the $1 \%$ level, and its coefficient was the same as the RP regression coefficient, which indicated that marketization was playing an enhanced moderating role on the effect of regulatory pressure on corporate green innovation; therefore hypotheses $4 \mathrm{a}$ and $5 \mathrm{a}$ were verified.

In Model 6, GI and NP were found to be significantly positively correlated at the $10 \%$ level, further verifying hypothesis 2 . The GI coefficients and the multiplication term NP*PI, and GI and the multiplication term NP*MI were not significant, which indicated that pollution intensity and marketization did not moderate the normative pressure and corporate green innovation relationship; therefore, hypotheses $4 \mathrm{~b}$ and $5 \mathrm{~b}$ were not verified.
In Model 7, GI and MP were found to be significantly positively correlated at the $1 \%$ level, further verifying hypothesis 3, and GI and the multiplication term MP*PI were significantly positively correlated at the $1 \%$ level, with the coefficient being the same as the regression coefficient $\mathrm{x} 3$, which indicated that pollution intensity was playing an enhanced moderating role on the effect of mimetic pressure on corporate green innovation. GI and the multiplication term MP*MI were found to be significantly positively correlated at the $5 \%$ level, with their coefficients being the same as the GI regression coefficients, which indicated that marketization was playing an enhanced moderating role on the effect of mimetic pressure on green innovation; therefore, hypotheses $4 \mathrm{c}$ and $5 \mathrm{c}$ were verified.

Table 4. Negative binomial estimations for the green innovation determinants: moderator effects.

\begin{tabular}{|c|c|c|c|c|c|c|c|}
\hline \multicolumn{8}{|c|}{ Dependent variable: green innovation } \\
\hline & Model 1 & Model 2 & Model 3 & Model 4 & Model 5 & Model 6 & Model 7 \\
\hline $\mathrm{RP}$ & $\begin{array}{l}0.2674^{* *} \\
(0.1072)\end{array}$ & & & $\begin{array}{l}0.3379^{* * *} \\
(0.1079)\end{array}$ & $\begin{array}{c}0.6222^{*} \\
(0.3597)\end{array}$ & & \\
\hline NP & & $\begin{array}{l}0.6100^{* * *} \\
(0.2347)\end{array}$ & & $\begin{array}{l}0.5464^{* *} \\
(0.2067)\end{array}$ & & $\begin{array}{c}0.1702^{*} \\
(0.6690)\end{array}$ & \\
\hline MP & & & $\begin{array}{l}4.4876^{* * *} \\
(1.2501)\end{array}$ & $\begin{array}{l}4.6320^{* * *} \\
(1.2345)\end{array}$ & & & $\begin{array}{c}14.7771^{* * *} \\
(4.8018)\end{array}$ \\
\hline PI & & & & & $\begin{array}{l}-1.7748 \\
(1.2756)\end{array}$ & $\begin{array}{l}-0.6429^{*} \\
(0.3488)\end{array}$ & $\begin{array}{l}0.9509^{* *} \\
(0.4367)\end{array}$ \\
\hline MI & & & & & $\begin{array}{c}-0.7656^{* * *} \\
(0.2944)\end{array}$ & $\begin{array}{c}0.0211 \\
(0.0668)\end{array}$ & $\begin{array}{c}0.0556 \\
(0.0615)\end{array}$ \\
\hline $\mathrm{RP} * \mathrm{PI}$ & & & & & $\begin{array}{l}0.2334^{* *} \\
(0.1985)\end{array}$ & & \\
\hline $\mathrm{RP} * \mathrm{MI}$ & & & & & $\begin{array}{c}0.1062^{* * *} \\
(0.0411)\end{array}$ & & \\
\hline NP*PI & & & & & & $\begin{array}{c}0.5091 \\
(0.5130)\end{array}$ & \\
\hline $\mathrm{NP} * \mathrm{MI}$ & & & & & & $\begin{array}{l}-0.0198 \\
(0.0796)\end{array}$ & \\
\hline MP*PI & & & & & & & $\begin{array}{c}15.2385^{* * *} \\
(4.0343)\end{array}$ \\
\hline $\mathrm{MP} * \mathrm{MI}$ & & & & & & & $\begin{array}{c}0.8985^{*} \\
(0.5281)\end{array}$ \\
\hline State & $\begin{array}{l}0.8559^{* * *} \\
(0.2879)\end{array}$ & $\begin{array}{l}0.7653^{* * *} \\
(0.2850)\end{array}$ & $\begin{array}{l}1.1682^{* * *} \\
(0.3106)\end{array}$ & $\begin{array}{l}1.1052^{* * *} \\
(0.3288)\end{array}$ & $\begin{array}{c}0.1964 \\
(0.1745)\end{array}$ & $\begin{array}{c}0.1783 \\
(0.1719)\end{array}$ & $\begin{array}{c}0.2190 \\
(0.1793)\end{array}$ \\
\hline Age & $\begin{array}{c}-0.1245^{* *} \\
(0.0237)\end{array}$ & $\begin{array}{c}-0.1269^{* * *} \\
(0.0232)\end{array}$ & $\begin{array}{c}-0.1306^{* * *} \\
(0.0234)\end{array}$ & $\begin{array}{c}-0.1338^{* * *} \\
(0.0251)\end{array}$ & $\begin{array}{c}-0.0405^{* * *} \\
(0.0135)\end{array}$ & $\begin{array}{c}-0.0419^{* * *} \\
(0.0135)\end{array}$ & $\begin{array}{c}-0.0435^{* * *} \\
(0.0138)\end{array}$ \\
\hline Size & $\begin{array}{c}0.0951^{*} \\
(0.0501)\end{array}$ & $\begin{array}{c}0.0519 \\
(0.0469)\end{array}$ & $\begin{array}{c}0.0219 \\
(0.0487)\end{array}$ & $\begin{array}{c}0.0675 \\
(0.0488)\end{array}$ & $\begin{array}{c}0.0602 \\
(0.0468)\end{array}$ & $\begin{array}{c}0.0251 \\
(0.0460)\end{array}$ & $\begin{array}{c}0.0160 \\
(0.0452)\end{array}$ \\
\hline FL & $\begin{array}{c}0.0055 \\
(0.0157)\end{array}$ & $\begin{array}{c}0.0065 \\
(0.0158)\end{array}$ & $\begin{array}{c}0.0112 \\
(0.0155)\end{array}$ & $\begin{array}{c}0.0154 \\
(0.0152)\end{array}$ & $\begin{array}{c}0.0078 \\
(0.0146)\end{array}$ & $\begin{array}{c}0.0084 \\
(0.0148)\end{array}$ & $\begin{array}{c}0.0131 \\
(0.0145)\end{array}$ \\
\hline Constant & $\begin{array}{l}-1.5452 \\
(1.5940)\end{array}$ & $\begin{array}{c}1.0615 \\
(1.1326)\end{array}$ & $\begin{array}{c}1.6454 \\
(1.1587)\end{array}$ & $\begin{array}{l}-2.0221 \\
(1.5818)\end{array}$ & $\begin{array}{c}4.6621 \\
(2.8766)\end{array}$ & $\begin{array}{c}0.9350 \\
(1.1366)\end{array}$ & $\begin{array}{c}0.3662 \\
(1.0823)\end{array}$ \\
\hline Log likelihood & -1169.2 & -1169.13 & -1165.90 & -1158.35 & -2032.8324 & -2039.3254 & -2027.8289 \\
\hline
\end{tabular}

Notes: $\mathrm{T}$ value is in brackets. 


\section{Robustness Test}

To further test the reliability of the conclusion that institutional pressure had an impact on green innovation, to reflect the green innovation degree, the core green innovation variable was replaced with the logarithm of the R \& D investment ratio to the listed company operating incomes (Models 8, 9, and 10), and the R \& D personnel proportion (Models 11, 12, and 13), the results for which are shown in Table 5, all of which confirmed the previous findings.

\section{Discussion}

In this study, negative binomial panel data estimations were used to test the impact of three different institutional pressures on the green technology innovation in listed Chinese manufacturing enterprises.
First, all three institutional pressure dimensions were found to have a significant positive relationship on green innovation, which provided support for the Porter hypothesis, that is, institutional pressures facilitate rather than inhibit corporate green innovation. This conclusion was at odds with the conventional economic view that because institutional pressures limit the use of certain raw materials and enterprise pollution emissions, enterprises experience increased production costs and reduced business performances [52, 53]. However, this conclusion was consistent with revisionist views which believe that to maintain legality and competitive advantage, companies are more willing to move to green innovation practices when they are under external environmental pressures [1,54-56]. Therefore, this study confirmed that the Porter hypothesis was also valid in emerging economies such as China in which there are strong institutional pressures. (1) The fear of punishment

Table 5. Robustness test results.

\begin{tabular}{|c|c|c|c|c|c|c|}
\hline & \multicolumn{6}{|c|}{ Dependent variable: green innovation } \\
\hline & Model 8 & Model 9 & Model 10 & Model 11 & Model 12 & Model 13 \\
\hline $\mathrm{RP}$ & $\begin{array}{l}0.4420^{* * *} \\
(0.1268)\end{array}$ & $\begin{array}{l}0.4749^{* * *} \\
(0.1505)\end{array}$ & $\begin{array}{l}0.4685^{* *} \\
(0.4648)\end{array}$ & $\begin{array}{l}0.0050^{* * *} \\
(0.0019)\end{array}$ & $\begin{array}{l}0.0076^{* * *} \\
(0.0024)\end{array}$ & $\begin{array}{c}0.0002^{*} \\
(0.0073)\end{array}$ \\
\hline NP & $\begin{array}{l}1.6797^{\text {*** }} \\
(0.8295)\end{array}$ & $\begin{array}{l}2.2544^{* *} \\
(0.8748)\end{array}$ & $\begin{array}{l}1.9944^{* * *} \\
(1.8833)\end{array}$ & $\begin{array}{l}0.0416^{* * *} \\
(0.0097)\end{array}$ & $\begin{array}{c}0.0374^{* * *} \\
(0.0118)\end{array}$ & $\begin{array}{l}0.0479^{* *} \\
(0.0232)\end{array}$ \\
\hline MP & $\begin{array}{l}0.3942^{* * *} \\
(2.2006)\end{array}$ & $\begin{array}{l}3.0511^{*} \\
(2.1471)\end{array}$ & $\begin{array}{l}-7.5898^{* * * *} \\
(7.5644)\end{array}$ & $\begin{array}{c}0.0197^{*} \\
(0.0218)\end{array}$ & $\begin{array}{l}0.0396^{* *} \\
(0.0266)\end{array}$ & $\begin{array}{l}0.0885^{* * *} \\
(0.0759)\end{array}$ \\
\hline PI & & $\begin{array}{c}1.6623 \\
(1.4691)\end{array}$ & & & $\begin{array}{l}-0.0120^{*} \\
(0.0202)\end{array}$ & \\
\hline MI & & & $\begin{array}{l}-0.0727 \\
(0.4382)\end{array}$ & & & $\begin{array}{l}0.0049^{* * *} \\
(0.0070)\end{array}$ \\
\hline $\mathrm{RP} * \mathrm{PI}$ & & $\begin{array}{c}-0.1776^{* *} \\
(0.3336)\end{array}$ & & & $\begin{array}{c}0.0026^{*} \\
(0.0040)\end{array}$ & \\
\hline $\mathrm{RP} * \mathrm{MI}$ & & & $\begin{array}{l}0.0125^{*} \\
(0.0596)\end{array}$ & & - & $\begin{array}{l}-0.0007^{* *} \\
(0.0010)\end{array}$ \\
\hline NP*PI & & $\begin{array}{l}-0.5030 \\
(0.8174) \\
\end{array}$ & & & $\begin{array}{l}-0.0138 \\
(0.0133) \\
\end{array}$ & \\
\hline NP*MI & & & $\begin{array}{c}0.0626 \\
(0.1602)\end{array}$ & & - & $\begin{array}{l}-0.0003 \\
(0.0020)\end{array}$ \\
\hline MP*PI & & $\begin{array}{l}-8.5496^{*} \\
(4.6018)\end{array}$ & & & $\begin{array}{l}-0.0521^{*} \\
(0.0424)\end{array}$ & \\
\hline $\mathrm{MP} * \mathrm{MI}$ & & & $\begin{array}{l}1.0007^{* *} \\
(0.9293)\end{array}$ & & & $\begin{array}{l}0.0148^{* * *} \\
(0.0101)\end{array}$ \\
\hline State & $\begin{array}{c}63.1657^{* * *} \\
(6.9897)\end{array}$ & $\begin{array}{c}63.0686^{* * *} \\
(9.3898)\end{array}$ & $\begin{array}{c}72.7814^{* * *} \\
(9.9626)\end{array}$ & $\begin{array}{l}1.2041^{* * *} \\
(0.0741)\end{array}$ & $\begin{array}{l}1.1403^{* * *} \\
(0.1270)\end{array}$ & $\begin{array}{l}1.2733^{* * *} \\
(0.1273)\end{array}$ \\
\hline Age & $\begin{array}{l}-2.6264^{* * *} \\
(0.3059)\end{array}$ & $\begin{array}{l}-2.6217^{* *} \\
(0.4096)\end{array}$ & $\begin{array}{l}-3.0411^{* * *} \\
(0.4345)\end{array}$ & $\begin{array}{c}-0.0515^{* * *} \\
(0.0032)\end{array}$ & $\begin{array}{c}-0.0488^{* * *} \\
(0.0055)\end{array}$ & $\begin{array}{c}-0.0545^{* * *} \\
(0.0056)\end{array}$ \\
\hline FL & $\begin{array}{l}-0.0202 \\
(0.0155)\end{array}$ & $\begin{array}{l}-0.0205 \\
(0.0155)\end{array}$ & $\begin{array}{l}-0.0176 \\
(0.0154)\end{array}$ & $\begin{array}{l}-0.0103 \\
(0.0055)\end{array}$ & $\begin{array}{l}-0.0106 \\
(0.0055)\end{array}$ & $\begin{array}{l}-0.0121 \\
(0.0054)\end{array}$ \\
\hline Constant & $\begin{array}{c}23.9470^{* * *} \\
(1.7968)\end{array}$ & $\begin{array}{c}23.7788^{* * *} \\
(1.8946)\end{array}$ & $\begin{array}{c}25.5831^{* * *} \\
(3.9895)\end{array}$ & $\begin{array}{l}0.2296^{* * *} \\
(0.0200)\end{array}$ & $\begin{array}{l}0.2433^{* * *} \\
(0.0212)\end{array}$ & $\begin{array}{l}0.2060^{* * *} \\
(0.0599)\end{array}$ \\
\hline R-squared & 0.8793 & 0.8810 & 0.8807 & 0.8762 & 0.8774 & 0.8772 \\
\hline
\end{tabular}

Notes: ${ }^{* * *} \mathrm{p}<0.01,{ }^{* *} \mathrm{p}<0.05,{ }^{*} \mathrm{p}<0.1$. 
from the mandatory environmental regulatory pressure was found to promote environmentally friendly behaviors. The Chinese government has promulgated a series of pollution prevention and pollution control policies focused on specific industries that also involve regular inspections, punishments and rewards. Because violating these environmental protection regulations can result in severe financial punishments and legal sanctions, enterprises are more willing to implement green innovation practices. (2) The environmental non-governmental organizations also place significant normative pressure on manufacturing enterprises, which in turn promotes green innovation. As society becomes more environmentally aware, public welfare organizations, enterprise supply chain partners, and consumers are seeking to purchase low emission, low energy consumption, and low pollution environmentally friendly products. In order to obtain the recognition of environmental non-governmental organizations and better environmental reputation in social media and the public, manufacturing enterprises tend to implement green innovation. (3) Mimetic pressure is also being felt from the successful green innovation practices of industry competitors and industry leaders. With increasing market competition incentives, the use of existing resources to develop differentiated technologies and products has become an important source of competitive advantage, especially in a global sustainable development context. Therefore, Chinese manufacturing enterprises are significantly affected by mimetic pressure from both domestic enterprises and international green product standards, which has made it imperative to implement green innovation development to maintain and improve market share.

Second, moderating normative pressure effects from pollution intensity and marketization on corporate green innovation were not found. Although these hypotheses were not supported, the results provided important and interesting insights. One possible reason for these results is that green innovation is affected by external institutional pressure and also the result of internal organizational factors. Although the resource allocation efficiency differs depending on the pollution intensity and marketization, when enterprises are faced with normative pressure, the driving behavior of internal organizations will play a stronger role, such as enterprise green cultural atmosphere, enterprise executives'environmental awareness, enterprise green human resource management, etc.

Third, both regulatory and mimetic pressure induce more green innovation in firms with higher levels of pollution intensity and marketization degree. In the places where the enterprises are located with high pollution intensity, the government needs to improve the environmental protection laws and regulations, also the supervision is strengthened, so the driving force of enterprise green innovation is stronger. In addition, the role of competitors and industry leaders of enterprises will be more obvious, because the environmental pressure perceived by enterprises will be greater than that in other places. As enterprises in regions that have high marketization are able to obtain the innovation resources they need from the market, they are more likely to succeed. On the contrary, with the low degree of marketization, enterprises do not have enough innovation resources to implement resource allocation.

\section{Conclusions}

Using A-share Chinese listed manufacturing industry data from 2012 to 2017, this study sought to assess the regulatory, normative, and mimetic pressure effects on corporate green innovation and examine the moderating role of pollution intensity and marketization. The empirical analysis found that: the regulatory, normative, and mimetic pressures all had a significant positive impact on corporate green innovation; pollution intensity and marketization played a positive moderating role on green innovation through regulatory and mimetic pressures; and pollution intensity and marketization had no moderating effects on normative pressure and green innovation.

\section{Practical Implications}

The synergistic effects of the regulatory, normative, and mimetic pressures were found to positively motivate corporate green technology innovation, which indicated that regulatory pressure needs to be balanced with the normative and mimetic pressures, and that it was very important to enhance the environmental protection awareness of the whole society to ensure a good environment for green technology innovation.

First, the government should consider the effect of industrial scale on green innovation, while providing tax incentives and institutional guarantee for enterprises to carry out R\&D activities. Provide more financing channels and financial subsidies for large-scale manufacturing enterprises, and provide low mortgage loans for small and medium-sized enterprises to help them develop rapidly.

Second, form a supervision mechanism of mutual restriction of "government-enterprises- public". On the one hand, government should standardize the green product market, formulate green product certification standards, strengthen the certification of green products in terms of energy saving, emission reduction and low carbon, provide consumers with identification standards of green products, and maintain the stability of green product market; On the other hand, government should pay attention to the environmental demands of consumers and supply chain partners, and regularly publish the environmental protection information of enterprises through the media, so that consumers and various environmental interest groups can understand and supervise the implementation of environmental protection behaviors of enterprises. 
Third, local governments need to pay greater attention to promoting environmental knowledge and environmental protection information to the public, and to increase the mimetic pressure, need to encourage local business leaders to improve their environmental commitments to motivate other industry enterprises to adopt green innovation practices.

Faced with strict government and public welfare environmental supervision and increases in public environmental protection awareness, enterprises need to see these environmental trends as offering opportunities to promote green development and improve their market share and competitiveness. The institutional and sustainable development theories both suggest that enterprise managers need to prioritize their stakeholders' future environmental protection needs by including environmental and sustainable development objectives in their enterprise strategies and business practices. Therefore, balancing the relationship between economic success and environmental protection is the key to successful sustainable development strategies.

\section{Limitations and Future Research Opportunities}

First, as this study was based on listed Chinese manufacturing companies, there were few SMEs included in the research sample; therefore, the conclusions may only be applied to larger enterprises in emerging economies. Second, as the primary focus was on manufacturing enterprises, other industry sectors need to be explored in future research to enrich the findings related to institutional pressures and enterprise green innovation.

\section{Acknowledgments}

We would like to acknowledge the anonymous reviewers and editors. We also thank the National Social Science Foundation of China (Grant no. 16AGL003), General Project of the Soft Science Research Program of Shanxi Province (Grant no. 2020KRM099), Sichuan Federation of Social Science Association (Grant no. SC21C053) and the China Scholarship Council for the financial support.

\section{Conflict of Interest}

The authors declare no conflict of interest.

\section{References}

1. GARCIA-GRANERO E.M., PIEDRA-MUNOZ L., GALDEANO-GOMEZ E.. Measuring eco-innovation dimensions: The role of environmental corporate culture and commercial orientation. Research Policy, 49 (8), 2020.
2. LUO Y., JIE X., LI X.. The organic joint point of new kinetic energy and green development in Chinese manufacturing SMEs. International Journal of Production Research, 1-23, 2020.

3. MASSOUDI A.H., FATAH S.J., AHMED M.E.. Incorporating Green Innovation to Enhance Environmental Sustainability. WSEAS Transactions on Business and Economics, 16, 477, 2019.

4. QIU L., JIE X., WANG Y., ZHAO M. Green product innovation, green dynamic capability, and competitive advantage: Evidence from Chinese manufacturing enterprises. Corporate Social Responsibility and Environmental Management, 27 (1), 146, 2020.

5. BERRONE P., FOSFURI A., GELABERT L., GOMEZMEJIA L.R. Necessity as the mother of 'green' inventions: Institutional pressures and environmental innovations. Strategic Management Journal, 34 (8), 891, 2013.

6. WU H., LIU S., HU S. Visible Hand: Do Government Subsidies Promote Green Innovation Performance Moderating Effect of Ownership Concentration. Polish Journal of Environmental Studies, 30 (1), 881, 2021.

7. EL-KASSAR A.-N., SINGH S.K. Green innovation and organizational performance: The influence of big data and the moderating role of management commitment and HR practices. Technological Forecasting and Social Change, 144, 483, 2019.

8. ALBORT-MORANT G., LEAL-MILLAN A., CEPEDACARRION G. The antecedents of green innovation performance: A model of learning and capabilities. Journal of Business Research, 69 (11), 4912, 2016.

9. DEMIREL P., KESIDOU E. Stimulating different types of eco-innovation in the UK: Government policies and firm motivations. Ecological Economics, 70 (8), 1546, 2011.

10. GUNARATHNE N., LEE, K.-H. Institutional pressures and corporate environmental management maturity. Management of Environmental Quality, 30 (1), 157, 2019.

11. KAWAI N., STRANGE R., ZUCCHELLA A. Stakeholder pressures, EMS implementation, and green innovation in $\mathrm{MNC}$ overseas subsidiaries. International Business Review, 27 (5), 933, 2018.

12. ZHANG F., ZHU L. Enhancing corporate sustainable development: Stakeholder pressures, organizational learning, and green innovation. Business Strategy and the Environment, 28 (6), 1012, 2019.

13. ZHANG B., WANG Z., LAI K.H. Mediating effect of managers' environmentalconcern: bridge between external pressures and firms' practices of energyconservation in China. Journal of Environmental Psychology. 43, 203, 2015.

14. DADDI T., TESTA F., FREY M., IRALDO F. Exploring the link between institutionalpressures and environmental management systems effectiveness: an empiricalstudy. Journal of Environmental Manage, 183, 647, 2016.

15. SONG W., YU H. Green Innovation Strategy and Green Innovation: The Roles of Green Creativity and Green Organizational Identity. Corporate Social Responsibility and Environmental Management, 25 (2), 135, 2018.

16. REN S.G., LI X.L., YUAN B.L., LI D.Y., CHEN X.H. The effects of three types of environmental regulation on ecoefficiency: A cross-region analysis in China. Journal of Cleaner Production, 173, 245, 2018.

17. AMBEC, STEFAN, COHEN, MARK A., ELGIE STEWART, LANOIE PAUL. The Porter Hypothesis at 20: Can Environmental Regulation Enhance Innovation and Competitiveness? Review of Environmental Economics and Policy, 7 (1), 2, 2013. 
18. KASSINIS G., VAFEAS N. Stakeholder pressures and environmental performance. Academy of Management Journal. 49 (1), 145, 2006.

19. AKSOM H., ZHYLINSKA O., GAIDAI T. Can institutional theory be refuted, replaced or modified? International Journal of Organizational Analysis, 28 (1), 135, 2020.

20. LEE M.-H., LIN C., LIN C.-K., LU W.-Y. Moderating effect of institutional responsiveness on the relationship between green leadership and green competitiveness. Social Behavior and Personality, 42 (9), 1483, 2014.

21. TESTA F., BOIRAL O., IRALDO F. Internalization of Environmental Practices and Institutional Complexity: Can Stakeholders Pressures Encourage Greenwashing? Journal of Business Ethics, 147 (2), 287, 2018.

22. MIGNERAT M., RIVARD S. The institutionalization of information system project management practices. Information and Organization, 22 (2), 125, 2012.

23. SUN H., EDZIAH B.K., SUN C., KPORSU A.K. Institutional quality, green innovation and energy efficiency. Energy Policy, 135, 2019.

24. HUANG XIAO-XING, HU ZHEN-PENG, LIU CUNSHAN, YU DA-JIN, YU LIU-FANG. The relationships between regulatory and customer pressure, green organizational responses, and green innovation performance. Journal of Cleaner Production, 112, 3423, 2016.

25. HARLEY G., TIMMIS A., BUDD L. Factors affecting environmental practice adoption at small European airports: An investigation. Transportation Research Part D-Transport and Environment, 88, 2020.

26. QIU L., HU D., WANG Y. How do firms achieve sustainability through green innovation under external pressures of environmental regulation and market turbulence? Business Strategy and the Environment, 29 (6), 2695, 2020.

27. XIE R.-H., YUAN Y.-J., HUANG J.-J. Different Types of Environmental Regulations and Heterogeneous Influence on "Green" Productivity: Evidence from China. Ecological Economics, 132, 104, 2017

28. RUBASHKINA Y., GALEOTTI M., VERDOLINI E. Environmental regulation and competitiveness: Empirical evidence on the Porter Hypothesis from European manufacturing sectors. Energy Policy, 83, 288, 2015.

29. LI BIN, WU SHUSHENG. Effects of local and civil environmental regulation on green total factor productivity in China: A spatial Durbin econometric analysis. Journal of Cleaner Production, 153 (1), 342, 2017.

30. YIN J., ZHANG Y. Institutional Dynamics and Corporate Social Responsibility (CSR) in an Emerging Country Context: Evidence from China. Journal of Business Ethics, 111 (2), 301, 2012.

31. WEBER K., THOMAS L.G., RAO H. From Streets to Suites: How the Anti-Biotech Movement Affected German Pharmaceutical Firms. American Sociological Review, 74 (1), 106, 2009.

32. MAGGIONI DANIELA, SANTANGELO, GRAZIA D. Local Environmental Non-Profit Organizations and the Green Investment Strategies of Family Firms. Ecological Economics, 138, 126, 2017.

33. ZHANG YIXIANG, WEI YIMIN, ZHOU GUANGHUI Promoting firms' energy-saving behavior: The role of institutional pressures, top management support and financial slack. Energy Policy, 115, 230, 2018.

34. KRELL KATHARINA, MATOOK SABINE, ROHDE FIONA The impact of legitimacy-based motives on IS adoption success: An institutional theory perspective. Information \& Management, 53 (6), 683, 2016.

35. ZHU QINGHUA. Institutional pressures and support from industrial zones for motivating sustainable production among Chinese manufacturers. International Journal of Production Economics, 181, 402, 2016.

36. LIN JIABAO, LUO ZHIMEI, LUO XIN Understanding the roles of institutional pressures and organizational innovativeness in contextualized transformation toward e-business: Evidence from agricultural firms. International Journal of Information Management, 51, 2020.

37. ZHU Q., GENG, Y. Drivers and barriers of extended supply chain practices for energy saving and emission reduction among Chinese manufacturers. Journal of Cleaner Production, 40, 6, 2013.

38. CHEN W., XIAO D., LIU W., WEI W. Interraction of pollution intensity, public environment concern, and government regulatuions in China: New evidence from 1993-2015 petition data. Journal of Environmental Protection and Ecology, 20, S682, 2019.

39. CHO, JOON HYUNG, SOHN, SO YOUNG A novel decomposition analysis of green patent applications for the evaluation of $\mathrm{R} \& \mathrm{D}$ efforts to reduce $\mathrm{CO}_{2}$ emissions from fossil fuel energy consumption. Journal of Cleaner Production, 193, 290, 2018.

40. DING WEINA, HAN BOTANG, ZHAO XIN, MAZZANTI MASSIMILIANO. How does green technology influence $\mathrm{CO}_{2}$ emission in China? - An empirical research based on provincial data of China. Journal of Environmental Biology, 36 (4), 745, 2015.

41. HART, STUART L., DOWELL GLEN. A NaturalResource-Based View of the Firm: Fifteen Years After. Journal of Management, 37 (5), 1464, 2011.

42. ZHAO X., WANG Z., DENG M. Interest Rate Marketization, Financing Constraints and R\&D Investments: Evidence from China. Sustainability, 11 (8), 2019.

43. GUO D., GUO Y., JIANG K. Funding forms, market conditions, and dydamic effects of governmenr R\&D subsides: evidence from China. Economic Inquiry, 55 (2), 825, 2017.

44. YI J., HONG J., HSU W.C., WANG C. Reprint of "The role of state ownership and institutions in the innovation performance of emerging market enterprises: Evidence from China". Technovation, 94, 2020.

45. LIN R.-J., TAN K.-H., GENG, Y. Market demand, green product innovation, and firm performance: evidence from Vietnam motorcycle industry. Journal of Cleaner Production, 40, 101, 2013.

46. LEE K.-H., MIN B. Green R\&D for eco-innovation and its impact on carbon emissions and firm performance. Journal of Cleaner Production, 108, 534, 2015.

47. KRAUS S., REHMAN S.U., SENDRA GARCIA F.J. Corporate social responsibility and environmental performance: The mediating role of environmental strategy and green innovation. Technological Forecasting and Social Change, 160, 2020.

48. LIN H., ZENG S.X., MA H.Y., QI G.Y., TAM V.W.Y. Can political capital drive corporate green innovation? Lessons from China. Journal of Cleaner Production, 64, 63, 2014.

49. LUO X., ZHANG W. Green innovation efficiency: a threshold effect of research and development. Clean Technologies and Environmental Policy, 2020.

50. SUN Z., WANG X., LIANG C., CAO F., WANG L. The impact of heterogeneous environmental regulation on 
innovation of high-tech enterprises in China: mediating and interaction effect. Environmental Science and Pollution Research, 2020.

51. COLE M.A., ELLIOTT R.J.R. Do environmental regulations influence trade patterns? Testing old and new trade theories. World Economy, 26 (8), 1163, 2003.

52. DANGELICO R.M., PUJARI D. Mainstreaming Green Product Innovation: Why and How Companies Integrate Environmental Sustainability. Journal of Business Ethics, 95 (3), 471, 2010.

53. HALL J., MATOS S., BACHOR V. From green technology development to green innovation: inducing regulatory adoption of pathogen detection technology for sustainable forestry. Small Business Economics, 52 (4), 877, 2019.
54. CAI W., LI G. The drivers of eco-innovation and its impact on performance: Evidence from China. Journal of Cleaner Production, 176, 110, 2018.

55. CHU Z., XU J., LAI F., COLLINS B.J. Institutional Theory and Environmental Pressures: The Moderating Effect of Market Uncertainty on Innovation and Firm Performance. Ieee Transactions on Engineering Management, 65 (3), 392, 2018.

56. DORAN J., RYAN G. The Importance of the Diverse Drivers and Types of Environmental Innovation for Firm Performance. Business Strategy and the Environment, 25 (2), 102, 2016 